\title{
Photocatalytic Degradation of Oxytetracycline Using Co-precipitation Method Prepared $\mathrm{Fe}_{2} \mathrm{O}_{3} / \mathrm{TiO}_{2}$ Nanocomposite
}

\author{
Yuefa $\mathrm{Jia}^{1}$, Chunli $\mathrm{Liu}^{1 *}$, and $\operatorname{Rong} \mathrm{Li}^{2 *}$ \\ ${ }^{1}$ Department of Physics and Oxide Research Center, Hankuk University of Foreign Studies, Yongin 17035, Korea \\ ${ }^{2}$ Research Center of Nano Science and Technology, Shanghai University, Shanghai 200444, China
}

(Received 30 December 2015, Received in final form 11 February 2016, Accepted 11 February 2016)

\begin{abstract}
$\mathrm{Fe}_{2} \mathrm{O}_{3} / \mathrm{TiO}_{2}$ nanocomposite were successfully synthesized by co-precipitation method using $\mathrm{Fe}\left(\mathrm{NO}_{3}\right)_{3} \cdot 9 \mathrm{H}_{2} \mathrm{O}$ and $\mathrm{Ti}\left(\mathrm{SO}_{4}\right)_{2}$ as raw materials. Structural and textural features of the mixed oxide samples were characterized by $\mathrm{X}$-ray diffractometer, field emission scanning electron microscopy and energy-dispersive X-ray. The effects of initial concentration of oxytetracycline (OTC), different competitive ions and organics on the photocatalytic degradation rate of OTC by the $\mathrm{Fe}_{2} \mathrm{O}_{3} / \mathrm{TiO}_{2}$ nanocomposite were analyzed under $\mathrm{UV}$ and visible light irradiation. The results indicate that the optimized initial concentration of OTC was $50 \mathrm{mg} / \mathrm{L}$ to achieve the best photocatalytic efficiency. $\mathrm{Cu}^{2+}, \mathrm{NH}_{4}^{+}, \mathrm{C}_{3} \mathrm{H}_{8} \mathrm{O}$ and EDTA in the aqueous suspension were found to suppress the degradation rate of OTC, whereas the effect of $\mathrm{NO}_{3}{ }^{-}$and $\mathrm{H}_{2} \mathrm{C}_{2} \mathrm{O}_{4}$ can be ignored.
\end{abstract}

Keywords : $\mathrm{Fe}_{2} \mathrm{O}_{3} / \mathrm{TiO}_{2}$, photocatalyst, competitive ions and organics, OTC

\section{Introduction}

Oxytetracycline (OTC) is one of the most widely used antibiotics in many fields [1,2], but has been frequently found to be contained in water bodies and sediments in many countries due to their poor absorption by human beings or livestocks $[3,4]$. To prevent the contamination of drinking water due to the spreading of OTC, various technologies, such as advanced oxidation processes (AOPs), biodegradable compounds and activated carbons adsorption [5-9], have been explored to remove OTC from the waste water system. Additionally, photocatalysis has been proposed as a promising approach due to the high efficiency in photodegradation of OTC [10]. Zhao et al. reported that $15 \% \mathrm{TiO}_{2}-5 \mathrm{~A}$ molecular sieve composite and $13 \mathrm{X}$ loaded with $\mathrm{TiO}_{2}$ photocatalysis showed a faster OTC removal and degradation speed than unsupported $\mathrm{TiO}_{2}$ under ultra-violet (UV) light $[11,12]$. Pereira et al. studied $\mathrm{TiO}_{2}$-assisted heterogeneous photocatalytic degradation and fully removal of OTC under solar UV energy [13]. In addition to UV light, visible light responsive $\mathrm{TiO}_{2}$, such as nitrogen and fluorine doped $\mathrm{TiO}_{2}$ film,

CThe Korean Magnetics Society. All rights reserved.

*Co-corresponding author: Tel: +82-31-330-4733

Fax:+82-31-330-4566, e-mail: chunliliu@hufs.ac.kr

Tel/Fax: +86-21-66137276, e-mail: lirong376@hotmail.com have also been investigated in the photodegradation experiments, and exhibited good degradation efficiency of OTC [14]. Recently, the photocatalytic response of OTC using $\mathrm{Fe}_{2} \mathrm{O}_{3} / \mathrm{TiO}_{2}$ nanocomposite has been investigated in details regarding the $\mathrm{pH}$ value and reaction mechanism [3], proposing that $\mathrm{Fe}_{2} \mathrm{O}_{3} / \mathrm{TiO}_{2}$ nanocomposite can be used as a promising material for OTC removal under visible light. The existence of $\mathrm{Fe}_{2} \mathrm{O}_{3}$ in the composite has been shown to widen the light absorption beyond the UV range and enhance the electron-hole separation, which consequently improve the photocatlytic efficiency of OTC [3]. In this work, we report the effect of initial OTC concentration and competitive species on the photocatalytic decomposition of OTC using $\mathrm{Fe}_{2} \mathrm{O}_{3} / \mathrm{TiO}_{2}$ nanocomposite under UV and visible lights.

\section{Experimental Section}

\subsection{Preparation of $\mathrm{Fe}_{2} \mathrm{O}_{3} / \mathrm{TiO}_{2}$ nanocomposite}

Using $\mathrm{Fe}\left(\mathrm{NO}_{3}\right)_{3} \cdot 9 \mathrm{H}_{2} \mathrm{O}$ and $\mathrm{Ti}\left(\mathrm{SO}_{4}\right)_{2}$ as raw materials, $\mathrm{Fe}_{2} \mathrm{O}_{3} / \mathrm{TiO}_{2}$ nanocomposite were synthesized using a coprecipitation method. A certain amount of $\mathrm{Fe}\left(\mathrm{NO}_{3}\right)_{3} \cdot 9 \mathrm{H}_{2} \mathrm{O}$ and $\mathrm{Ti}\left(\mathrm{SO}_{4}\right)_{2}$ was firstly dissolved in $10 \mathrm{ml}$ diluted sulfuric acid, then mixed with $500 \mathrm{ml}$ ethanol to form a metal ion solution. Next, the ammonia solution was added drop by drop to the metal solution with continuously stirring at room temperature to maintain the $\mathrm{pH}$ value of 
the solution around 8-9. Red colored precipitates were obtained after the solution was aged overnight. The precipitates were filtered, washed with deionized water till no $\mathrm{SO}_{4}{ }^{2-}$ could be tested with $\mathrm{Ba}^{2+}$, and dried at 100 ${ }^{\circ} \mathrm{C}$ for $12 \mathrm{~h}$ to obtain the precursor. Finally, the precursors were calcined at $500{ }^{\circ} \mathrm{C}$ for $4 \mathrm{~h}$. For comparison, pure anatase $\mathrm{TiO}_{2}$ and hematite $\mathrm{Fe}_{2} \mathrm{O}_{3}$ were also synthesized by precipitation method as A. K. Tripathi et al. and $\mathrm{M}$. Mishra et al. reported [15, 16].

\subsection{Characterization of Physical properties and photo-} catalytic activity.

The phases of the co-precipitation products were analyzed by a D/Max-2200(Japan) X-ray diffractometer. The microstructure of $\mathrm{Fe}_{2} \mathrm{O}_{3} / \mathrm{TiO}_{2}$ nanocomposite was observed via a field emission scanning electron microscopy (FESEM, Hitachi-S4800, Japan) equipped with energydispersive X-ray (EDX).

The photocatalytic degradation experiments were carried out using oxytetracycline hydrochloride (OTC $\cdot \mathrm{HCl}, 95 \%$ purity, Aladdin Chemistry Co., Ltd, Shanghai, China) and the $\mathrm{Fe}_{2} \mathrm{O}_{3} / \mathrm{TiO}_{2}$ nanocomposite under both UV and visible light radiation. A $300 \mathrm{~W}$ iodine tungsten lamp and highpressure mercury lamp (main wavelength of 250-400 nm) was used as the visible/UV light source. The detailed measurement process has been reported in our previous work [3].

\section{Results and Discussion}

\subsection{Crystallinity and morphology of the $\mathrm{Fe}_{2} \mathrm{O}_{3} / \mathrm{TiO}_{2}$} nanocomposite

The crystallographic information associated with $\mathrm{Fe}_{2} \mathrm{O}_{3} /$ $\mathrm{TiO}_{2}$ nanocomposite, pure anatase $\mathrm{TiO}_{2}$, and hematite

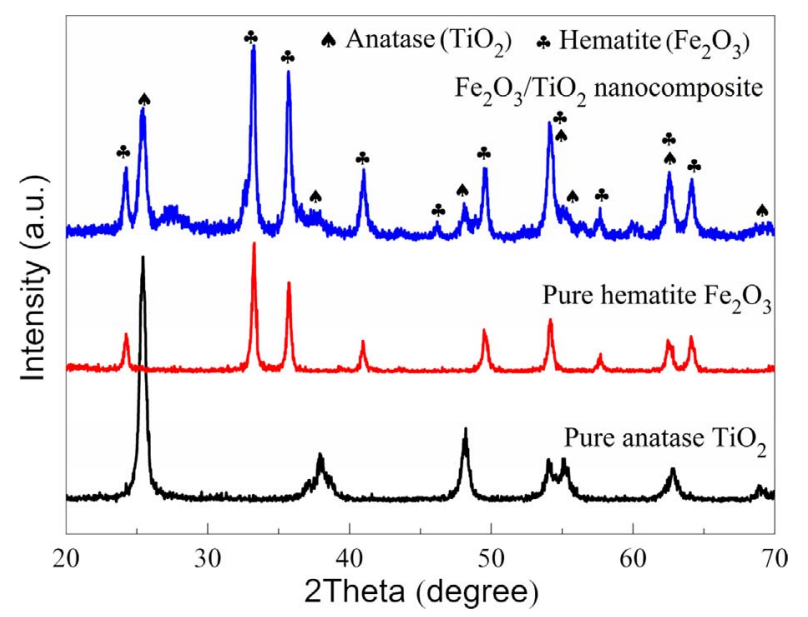

Fig. 1. (Color online) XRD pattern of $\mathrm{Fe}_{2} \mathrm{O}_{3} / \mathrm{TiO}_{2}$ nanocomposite, pure anatase $\mathrm{TiO}_{2}$ and hematite $\mathrm{Fe}_{2} \mathrm{O}_{3}$.
$\mathrm{Fe}_{2} \mathrm{O}_{3}$ has been investigated by XRD, as illustrated in Fig. 1. The main phases in $\mathrm{Fe}_{2} \mathrm{O}_{3} / \mathrm{TiO}_{2}$ nanocomposite are anatase $\mathrm{TiO}_{2}$ (JCPDS card No.21-1272) and hematite $\mathrm{Fe}_{2} \mathrm{O}_{3}$ (JCPDS card No.33-0664). Through the Scherrer equation:

$$
D=\frac{K \lambda}{\beta \cos \theta}
$$

where $K$ refers to a constant of $0.89, \beta$ is the full width at half maximum (FWHM) of the XRD peak at the diffraction angle $\theta$, and $\lambda$ is X-ray wavelengths of 0.154 $\mathrm{nm}$, the grain size $D$ is estimated as $25 \mathrm{~nm}$ and $17 \mathrm{~nm}$ for $\mathrm{TiO}_{2}$ and $\mathrm{Fe}_{2} \mathrm{O}_{3}$ particles in the $\mathrm{Fe}_{2} \mathrm{O}_{3} / \mathrm{TiO}_{2}$ nanocomposite, respectively. No other impurity diffraction peak is seen, which confirms the purity of the sample. HRSEM images of $\mathrm{Fe}_{2} \mathrm{O}_{3} / \mathrm{TiO}_{2}$ nanocomposite are shown in Fig. 2 (a). Two morphologies including nanorod and nanosphere were observed in the nanocomposite. The particle size of $\mathrm{Fe}_{2} \mathrm{O}_{3} / \mathrm{TiO}_{2}$ nanocomposite is about $50 \pm 2 \mathrm{~nm}$. In addition, EDX was detected at point 1 and the spectrum is shown in Fig. 2(b). The observed elements are Ti, $\mathrm{O}$ and Fe present in the given sample.

\subsection{Photodegradation rate of OTC by $\mathrm{Fe}_{2} \mathrm{O}_{3} / \mathrm{TiO}_{2}$ nanocomposite}
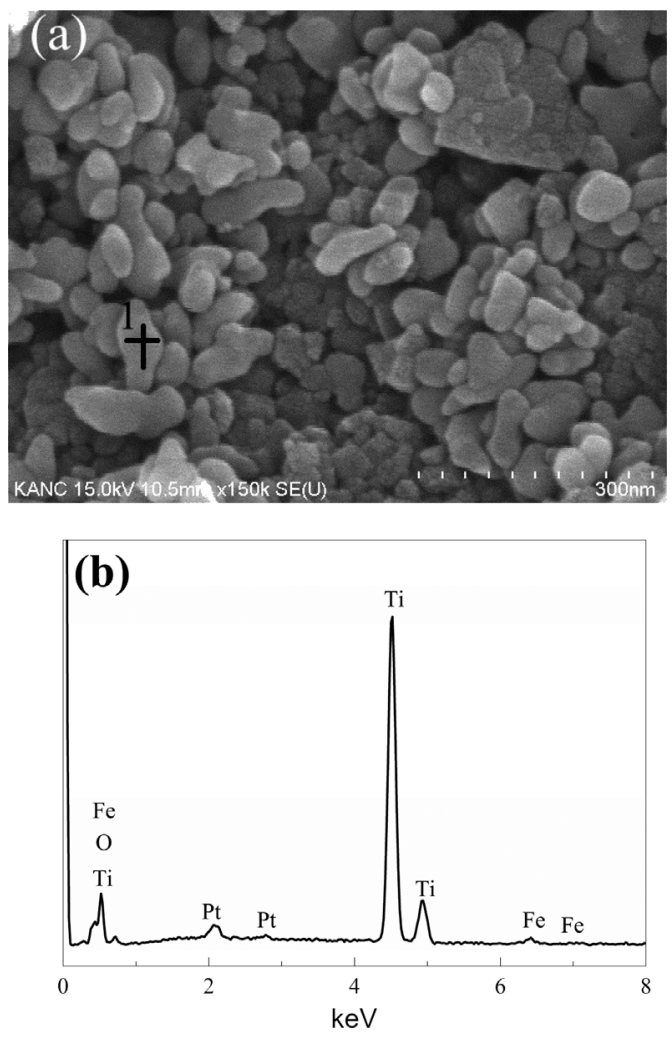

Fig. 2. HRSEM of $\mathrm{Fe}_{2} \mathrm{O}_{3} / \mathrm{TiO}_{2}$ nanocomposite (a) and (b) EDX analysis of point 1 . 

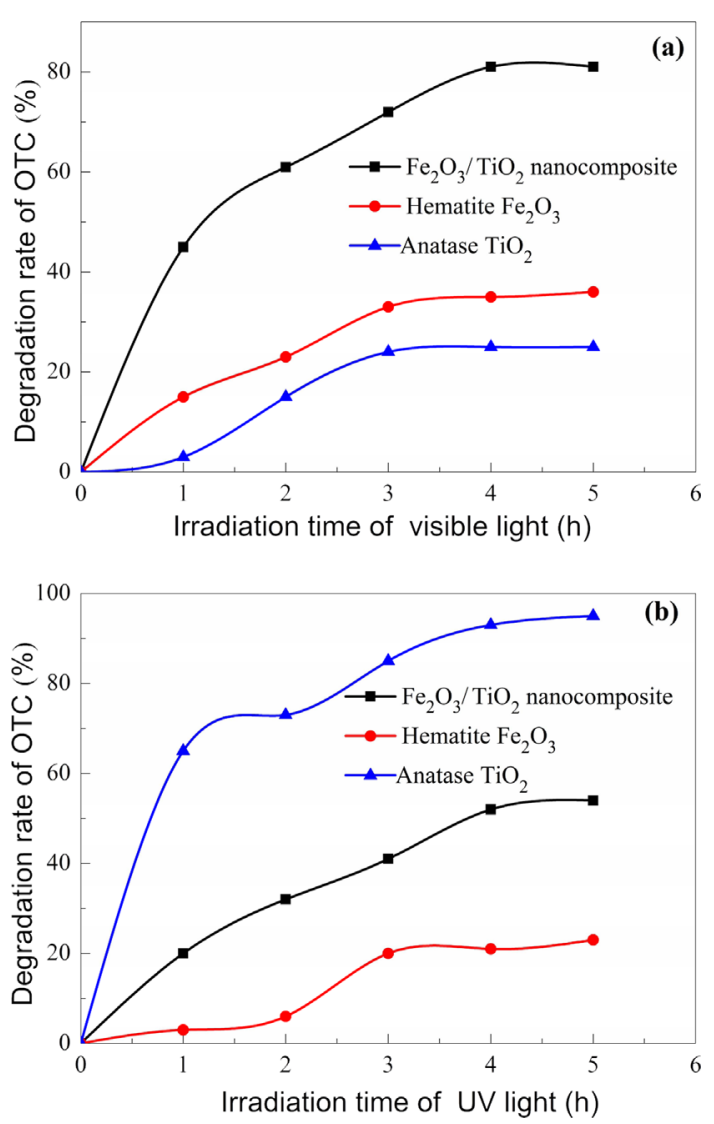

Fig. 3. (Color online) Degradation rate of OTC over pure anatase $\mathrm{TiO}_{2}$, hematite $\mathrm{Fe}_{2} \mathrm{O}_{3}$ and $\mathrm{Fe}_{2} \mathrm{O}_{3} / \mathrm{TiO}_{2}$ nanocomposite $\left(\mathrm{C}_{0}=50 \mathrm{mg} / \mathrm{L}\right)$ under visible light (a) and $\mathrm{UV}(\mathrm{b})$.

Fig. 3 gives the photocatalytic degradation rate of OTC under $\mathrm{UV} /$ visible light as a function of irradiation time. The degradation curve using pure anatase $\mathrm{TiO}_{2}$ and hematite $\mathrm{Fe}_{2} \mathrm{O}_{3}$ are also given for comparison. Under visible light for $5 \mathrm{~h}$, the photodegradation rates of $81 \%, 36 \%$ and $25 \%$ can be observed for $\mathrm{Fe}_{2} \mathrm{O}_{3} / \mathrm{TiO}_{2}$ nanocomposite, hematite $\mathrm{Fe}_{2} \mathrm{O}_{3}$ and pure anatase $\mathrm{TiO}_{2}$, respectively. With similar conditions but UV light, photodegradation rates are 54\%, $23 \%$ and $95 \%$ for $\mathrm{Fe}_{2} \mathrm{O}_{3} / \mathrm{TiO}_{2}$ nanocomposite, hematite $\mathrm{Fe}_{2} \mathrm{O}_{3}$ and pure anatase $\mathrm{TiO}_{2}$, respectively. Since visible light occupies about $50 \%$ of the solar spectrum, $\mathrm{Fe}_{2} \mathrm{O}_{3} /$ $\mathrm{TiO}_{2}$ nanocomposite are good candidates for further application in the waste water treatment containing OTC or similar materials.

\subsection{Effect of initial OTC concentration on the photo- catalytic degradation}

As shown in the inset of Fig. 4(a), OTC has a quite stable naphthacene ring structure, which results in its antibiotic and hydrophilic characteristics. Therefore, OTC is hard to remove by the conventional water treatment processes. The photocatalytic degradation of OTC using
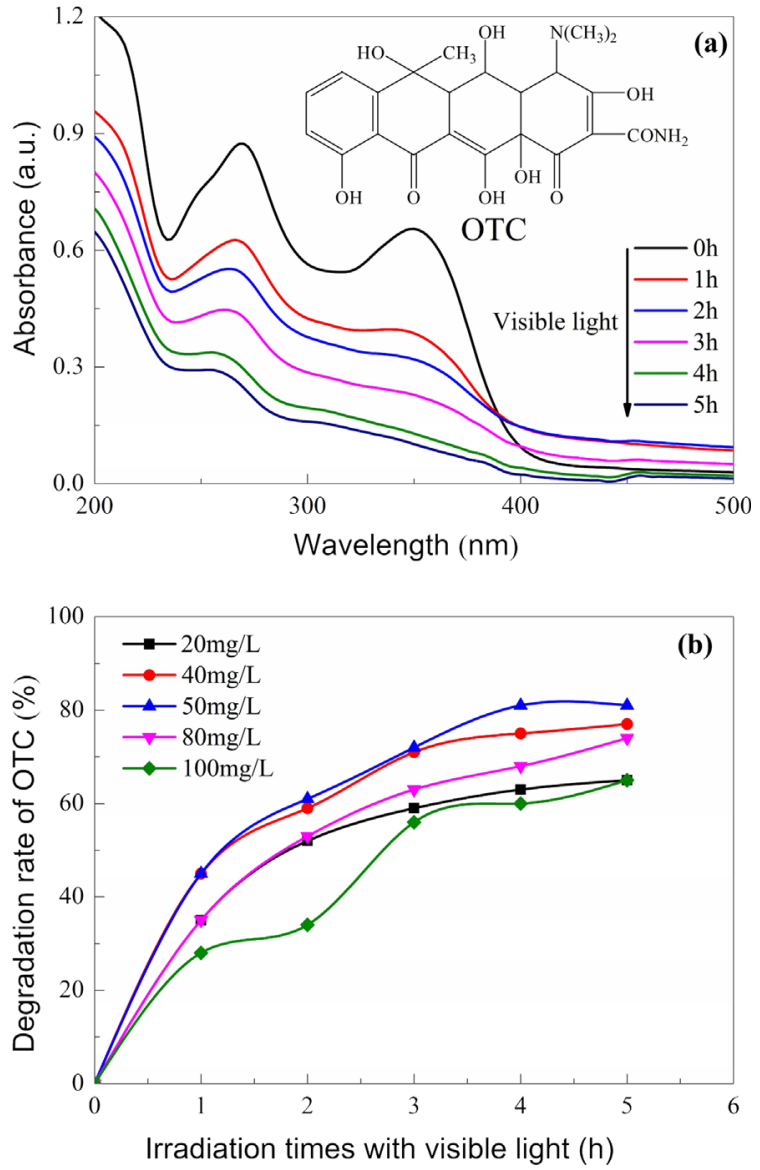

Fig. 4. (Color online) (a) UV-vis spectal variation of OTC solution with reaction time over $\mathrm{Fe}_{2} \mathrm{O}_{3} / \mathrm{TiO}_{2}$ nanocomposite $\left(\mathrm{C}_{0}=50 \mathrm{mg} / \mathrm{L}\right)$ under visible light, inset figure shows chemical structures of OTC. (b)The variation of degradation rate (\%) of OTC on different initial concentration $\left(\mathrm{C}_{0}=20,40,50\right.$, 70 and $100 \mathrm{mg} / \mathrm{L}$ ) under visible light.

$\mathrm{Fe}_{2} \mathrm{O}_{3} / \mathrm{TiO}_{2}$ nanocomposite as a function of the visible light irradiation time is shown in Fig. 4(a). The main absorption peaks of OTC $\left(\mathrm{C}_{0}=50 \mathrm{mg} / \mathrm{L}\right)$ at $270 \mathrm{~nm}$ and $353 \mathrm{~nm}$ are significantly reduced after $5 \mathrm{~h}$, indicating the removal of a large amount of OTC by $\mathrm{Fe}_{2} \mathrm{O}_{3} / \mathrm{TiO}_{2}$ nanocomposite under the visible light irridation. Additionally, testing solutions with various initial concentration of OTC $(20,40,50,70$ and $100 \mathrm{mg} / \mathrm{L}$, under visible light) were used as shown in Fig. 4(b). One can notice a remarkable increase in the degradation rate of OTC with the initial concentration increasing to $50 \mathrm{mg} / \mathrm{L}$, which implying a balance point between the surface area of the catalyst and the amount of reactive intermediates in the testing solution. Further increase of the initial OTC concentration causes a lower degradation rate, which can be attributed to the insufficient contact between OTC and the photocatalyst due to the presence of more reactive intermediates on the surface of the $\mathrm{Fe}_{2} \mathrm{O}_{3} / \mathrm{TiO}_{2}$ nanocomposite. 

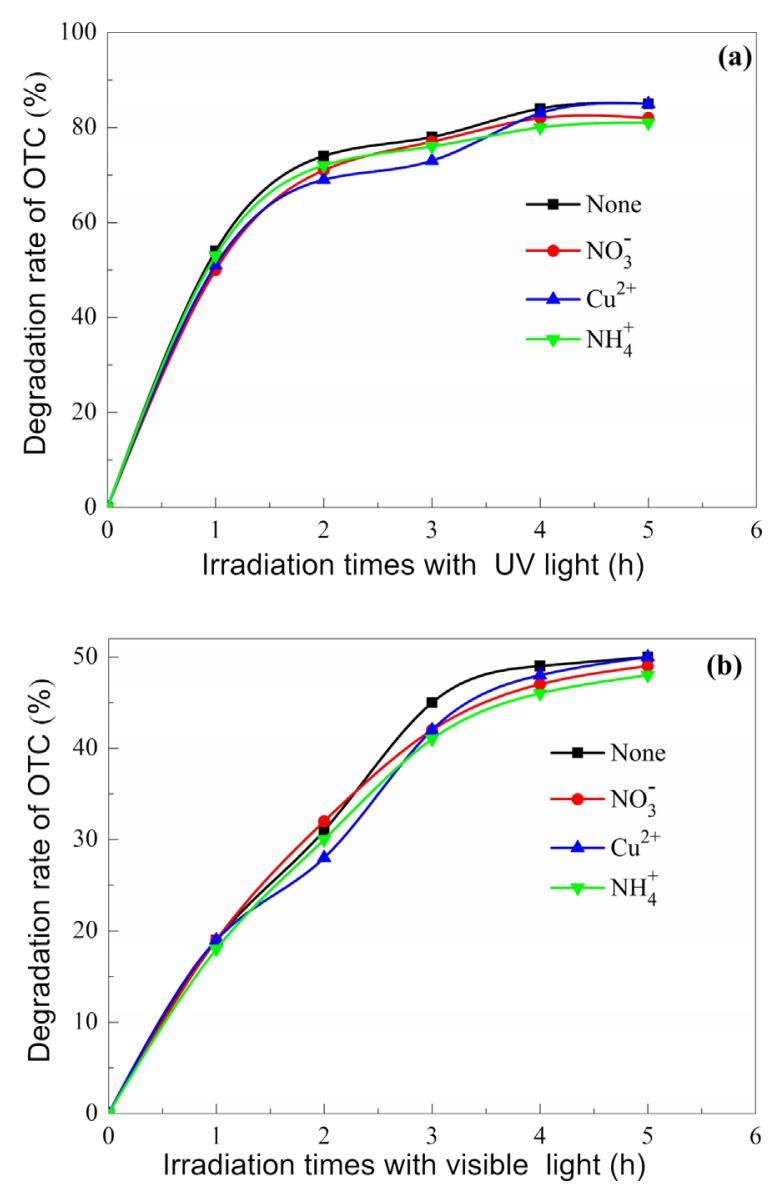

Fig. 5. (Color online) Effect of competitive ions $(0.5 \mathrm{mmol} / \mathrm{L})$ on degradation rate $(\%)$ of OTC solution $(50 \mathrm{mg} / \mathrm{L})$ under UV (a) and visible light (b) with $\mathrm{Fe}_{2} \mathrm{O}_{3} / \mathrm{TiO}_{2}$ nanocomposite.

3.4. Effect of competitive ions and organics on the photocatalytic degradation

$\mathrm{NO}_{3}{ }^{-}, \mathrm{NH}_{4}{ }^{+}, \mathrm{Cu}^{2+}, \mathrm{C}_{3} \mathrm{H}_{8} \mathrm{O}$, EDTA, or $\mathrm{C}_{2} \mathrm{H}_{2} \mathrm{O}_{4}$ often exist in the waste water environment, and their presence could affect the degradation rate of OTC by attaching or reacting with the active sites of the photocatalyst. Therefore, $\mathrm{NaNO}_{3}, \mathrm{NH}_{4} \mathrm{Cl}, \mathrm{CuCl}_{2}$, isopropano $\left(\mathrm{C}_{3} \mathrm{H}_{8} \mathrm{O}\right)$, ethylene diamine tetraacetic acid (EDTA) or oxalic acid $\left(\mathrm{C}_{2} \mathrm{H}_{2} \mathrm{O}_{4}\right)$ were dissolved in distilled water together with OTC to study the effect of different competitive ions and organics. The concentrations of $\mathrm{NO}_{3}^{-}, \mathrm{NH}_{4}^{+}, \mathrm{Cu}^{2+}, \mathrm{C}_{3} \mathrm{H}_{8} \mathrm{O}$, EDTA, or $\mathrm{C}_{2} \mathrm{H}_{2} \mathrm{O}_{4}$ were all adjusted as $0.5 \mathrm{mmol} / \mathrm{L}$.

In Fig. 5(a) and (b), competitive ions $\mathrm{NO}_{3}{ }^{-}, \mathrm{NH}_{4}{ }^{+}, \mathrm{Cu}^{2+}$ $(0.5 \mathrm{mmol} / \mathrm{L})$ all showed a general trend of reducing the degradation rate of OTC $(50 \mathrm{mg} / \mathrm{L})$ under UV and visible light. While $\mathrm{NO}_{3}{ }^{-}$and $\mathrm{Cu}^{2+}$ ions exhibited minimal or negligible impacts, $\mathrm{NH}_{4}{ }^{+}$showed a much significant effect in suppressing the degradation efficiency. Normally, the $\mathrm{NO}_{3}{ }^{-}$exhibited minimal or negligible impacts on degradation efficiency of OTC, because reactive species
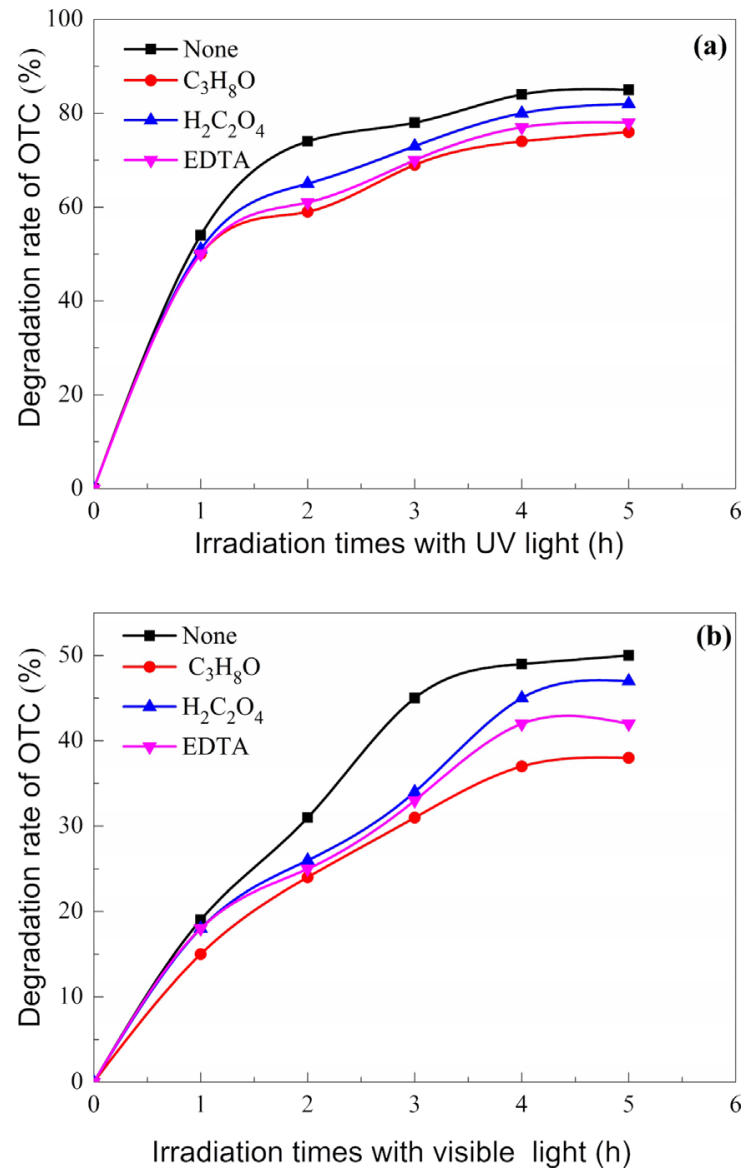

Fig. 6. (Color online) Effect of competitive organics $(0.5$ $\mathrm{mmol} / \mathrm{L})$ on degradation rate $(\%)$ of OTC solution $(50 \mathrm{mg} / \mathrm{L})$ under UV (a) and visible light (b) with $\mathrm{Fe}_{2} \mathrm{O}_{3} / \mathrm{TiO}_{2}$ nanocomposite.

can be generated in nitrate solution which elevated OTC photolysis efficiency [17]. It has been reported that $\mathrm{Cu}^{2+}$ enhanced the adsorption of tetracyclines (TC) via acting as a bridge ion to form goethite- $\mathrm{Cu}^{2+}$-tetracycline surface complex [18]. Since the structure of OTC is similar to TC, $\mathrm{Cu}^{2+}$ can also enhanced adsorption of OTC on the surface of $\mathrm{Fe}_{2} \mathrm{O}_{3} / \mathrm{TiO}_{2}$ nanocomposite. However, the $\mathrm{NH}_{4}{ }^{+}$ have greatly suppressed on degradation rate of OTC, because the relationship between $\mathrm{Fe}_{2} \mathrm{O}_{3} / \mathrm{TiO}_{2}$ nanocomposite and $\mathrm{NH}_{4}{ }^{+}$is only competitive adsorption.

Effect of competitive organic $(0.5 \mathrm{mmol} / \mathrm{L})$ on the degradation rate of OTC $(50 \mathrm{mg} / \mathrm{L})$ solution are shown in Fig. 6. Among the three different organic species tested in this work, $\mathrm{H}_{2} \mathrm{C}_{2} \mathrm{O}_{4}$ showed less effect than $\mathrm{C}_{3} \mathrm{H}_{8} \mathrm{O}$ and EDTA. Although $\mathrm{HC}_{2} \mathrm{O}_{4}^{-}$generated from $\mathrm{H}_{2} \mathrm{C}_{2} \mathrm{O}_{4}$ can compete with neutral-zwitterionic $\left(\mathrm{H}_{3} \mathrm{OTC}^{ \pm}\right)$generated from OTC for preferential adsorption on the surface of catalyst [19], reaction between $\mathrm{H}_{2} \mathrm{C}_{2} \mathrm{O}_{4}$ and $\mathrm{Fe}^{2+}$ under irradiation can also form the highly active intermediate 
-OH radicals, which may improve the decomposition rate of OTC [20]. The significant suppression of the photocatalytic efficiency with the presence of $\mathrm{C}_{3} \mathrm{H}_{8} \mathrm{O}$ and EDTA can be understood considering the fact that $\mathrm{C}_{3} \mathrm{H}_{8} \mathrm{O}$ is known as $\cdot \mathrm{OH}$ radical scavengers [21] and $\mathrm{Fe}^{3+}$-EDTA can be formed by reactions of EDTA $^{2-}$ with iron oxides at $\mathrm{pH}<7$ [22], which inhibited the degradation rate of OTC.

\section{Conclusions}

In summary, we synthesized $\mathrm{Fe}_{2} \mathrm{O}_{3} / \mathrm{TiO}_{2}$ nanocomposite by co-precipitation method using $\mathrm{Fe}\left(\mathrm{NO}_{3}\right)_{3} \cdot 9 \mathrm{H}_{2} \mathrm{O}$ and $\mathrm{Ti}$ $\left(\mathrm{SO}_{4}\right)_{2}$ as raw materials, and characterized by $\mathrm{XRD}, \mathrm{HR}-$ SEM and EDX. These results showed that $\mathrm{Fe}_{2} \mathrm{O}_{3} / \mathrm{TiO}_{2}$ nanocomposite consisted of hematite $\mathrm{Fe}_{2} \mathrm{O}_{3}$ and anatase $\mathrm{TiO}_{2}$ with particle size of $50 \pm 2 \mathrm{~nm}$. The photocatalytic measurements indicated that by using $\mathrm{Fe}_{2} \mathrm{O}_{3} / \mathrm{TiO}_{2}$ nanocomposite of $1 \mathrm{~g} / \mathrm{L}$, the highest efficiency of OTC degradation can be achieved when the initial concentration of OTC was $50 \mathrm{mg} / \mathrm{L}$. Additionally, the investigation of the competitive ions and organics showed that although the existence of $\mathrm{NO}_{3}^{-}$and $\mathrm{H}_{2} \mathrm{C}_{2} \mathrm{O}_{4}$ can be ignored, $\mathrm{Cu}^{2+}$, $\mathrm{NH}_{4}{ }^{+}, \mathrm{C}_{3} \mathrm{H}_{8} \mathrm{O}$ and EDTA in aqueous suspension significantly inhibited the degradation efficiency of OTC.

\section{Acknowledgements}

The authors would like to thank Instrumental Analysis and Research Center of Shanghai University for the experimental assistance on the XRD. SEM characterization in this research was supported by Nano-material Technology Development Program through the National Research Foundation of Korea (NRF) funded by the Ministry of Science, ICT and Future Planning (20090082580). This work was supported by the Hankuk University of Foreign Studies Research Fund of 2016.

\section{References}

[1] A. K. Singh, G. Rathore, V. Sing, I. Mani, R. K. Singh, S. K. Mishra, B. N. Mishra, and O. P. Verma, Int. J. Microbiol. Res. 1, 25 (2009).

[2] M. Rabolle and N. H. Spliid, Chemosphere 40, 715
(2000).

[3] R. Li, Y. F. Jia, J. Wu, and Q. Zhen, RSC Adv. 5, 40764 (2015).

[4] A. J. Watkinson, E. J. Murbyd, D. W. Kolpine, and S. D. Costanzof, Sci. Total. Environ. 407, 2711 (2009).

[5] S. G. Segura and E. Brillas, Water Res. 45, 75 (2011).

[6] M. H. Khan, H. Bae, and J. Y. Jung, J. Hazard. Mater. 181, 659 (2010).

[7] O. U. Merih and A. K. B. Isil, J. Agric. Food. Chem. 57, 11284 (2009).

[8] L. Migliore, M. Fiori, A. Spadoni, and E. Galli, J. Hazard. Mater. 215-216, 227 (2012).

[9] L. H. Huang, Y. Y. Sun, W. L. Wang, Q. Y. Yue, and T. Yang, Chem. Eng. J. 171, 1446 (2011).

[10] J. H. O. S. Pereira, V. J. P. Vilar, M. T. Borges, O. González, S. Esplugas, and R. A. R. Boaventura, Sol. Energy 85, 2732 (2011).

[11] C. Zhao, Y. Zhou, D. R. D. Johannes, J. Zhai, D. R. Zhai, J. Y. Wei, and H. P. Deng, Chem. Eng. J. 248, 280 (2014).

[12] C. Zhao, H. P. Deng, Y. Li, and Z. H. Liu, J. Hazard. Mater. 176, 884 (2010).

[13] J. H. O. S. Pereira, A. C. Reis, D. Queirós, O. C. Nunes, M. T. Borges, V. J. P. Vilar, and R. A. R. Boaventura, Sci. Total. Environ. 463-464, 274 (2013).

[14] X. L. Liu, P. Lv, G. X. Yao, C. C. Ma, P. W. Huo, and Y. S. Yan, Chem. Eng. J. 217, 398 (2013).

[15] A. K. Tripathi, M. C. Mathpal, P. Kumar, M. K. Singh, S. K. Mishra, R. K. Srivastava, J. S. Chung, G. Verma, M. M. Ahmad, and A. Agarwal. Mat. Sci. Semicon. Proc. 23, 136 (2014).

[16] M. Mishra, H. Park, and D. M. Chun, Adv. Powder Technol (in press). http://dx. doi.org/10.1016/j.apt.2015.11.009.

[17] M. W. Lam, K. Tantuco, and S. A. Mabury, Environ. Sci. Technol. 37, 899 (2003).

[18] Y. P. Zhao, J. J. Geng, X. R. Wang, X. Y. Gu, and S. X. Gao, J. Colloid and Interf Sci. 361, 247 (2011).

[19] Z. Q. He, X. Xu, S. Song, L. Xie, J. J. Tu, J. M. Chen, and B. Yan, J. Phys. Chem. C 112, 16431 (2008).

[20] S. Q. Liu, L. R. Feng, N. Xu, Z. G. Chen, and X. M. Wang, Chem. Eng. J. 203, 432 (2013).

[21] W. Zhou, H. G. Fu, K. Pan, C. G. Tian, Y. Qu, P. P. Lu, and C. C. Sun, J. Phys. Chem. C 112, 19584 (2008).

[22] W. Bernd, L. Johannes, B. Philippe, and S. Laura, Environ. Sci. Technol. 30, 2397 (1996). 